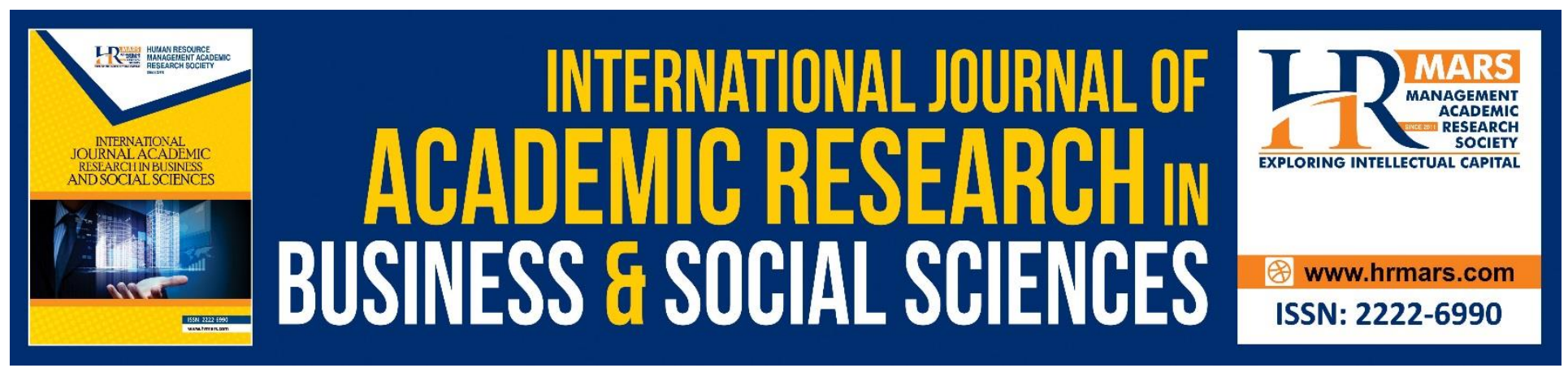

\title{
Parental Perceptions of Childcare Service Quality: A Descriptive Analysis
}

Nik Syuhailah Nik Hussin, Safiek Mokhlis, Hayatul Safrah Salleh

To Link this Article: http://dx.doi.org/10.6007/IJARBSS/v9-i2/5658 $\quad$ DOI: $10.6007 /$ IJARBSS/v9-i2/5658

Received: 21 Jan 2019, Revised: 15 Feb 2019, Accepted: 08 March 2019

Published Online: 09 March 2019

In-Text Citation: (Hussin, Mokhlis, \& Salleh, 2019)

To Cite this Article: Hussin, N. S. N., Mokhlis, S., \& Salleh, H. S. (2019). Parental Perceptions of Childcare Service Quality: A Descriptive Analysis. International Journal of Academic Research in Business and Social Sciences, 9(2), 1004-1013.

Copyright: (c) 2019 The Author(s)

Published by Human Resource Management Academic Research Society (www.hrmars.com)

This article is published under the Creative Commons Attribution (CC BY 4.0) license. Anyone may reproduce, distribute, translate and create derivative works of this article (for both commercial and non-commercial purposes), subject to full attribution to the original publication and authors. The full terms of this license may be seen at: http://creativecommons.org/licences/by/4.0/legalcode

Vol. 9, No. 2, 2019, Pg. 1004 - 1013

http://hrmars.com/index.php/pages/detail/IJARBSS

JOURNAL HOMEPAGE

Full Terms \& Conditions of access and use can be found at http://hrmars.com/index.php/pages/detail/publication-ethics 


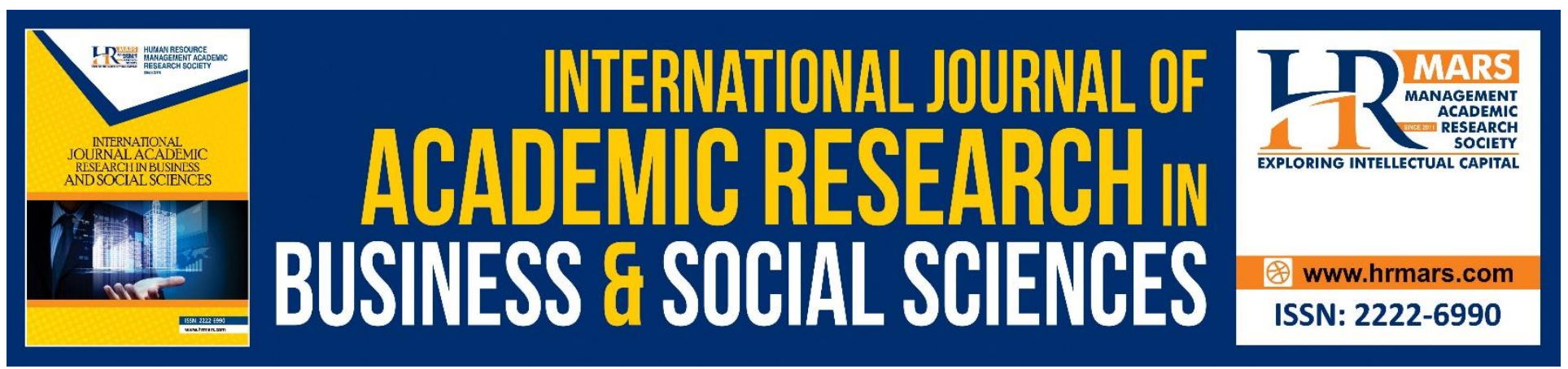

\title{
Parental Perceptions of Childcare Service Quality: A Descriptive Analysis
}

\author{
${ }^{1}$ Nik Syuhailah Nik Hussin, ${ }^{2}$ Safiek Mokhlis, ${ }^{2}$ Hayatul Safrah Salleh \\ ${ }^{1}$ Universiti Malaysia Terengganu/ Universiti Malaysia Kelantan \\ ${ }^{2}$ Universiti Malaysia Terengganu
}

\begin{abstract}
In these recent years, the involvement of women in the workforce to combat high cost of living and financial socioeconomics has led to reliance to childcare centers. The objective of the study is to examine the service quality factors of childcare centers. The respondents in this study are referred to working parents who send their children to childcare centers. A total of 150 questionnaires were distributed to respondents in Kelantan and Terengganu. Data analysis was conducted using SPSS 20.0 and the result indicated various factors of service quality being anticipated by the parents. The findings found that there were criteria expected by the working parents when they leaving their children to childcare.
\end{abstract}

Keywords: Childcare, Service Quality, Descriptive Analysis, Servperf, Perceptions

\section{Introduction}

In Malaysia, the number of childcare centers are mounting steadily and are projected to continue to increase in the forthcoming years. A significant increase in number of registered childcare centers were reported, namely 2194 units in 2013 and 4240 units in June 2016. The Malaysian Deputy Prime Minister highlighted that 38,333 childcare centers are needed to cater the needs of children under four years old and urged for more private institutions to look upon this matter under full governmental support (Abas \& Noor, 2018). This is in line with the growing number of women in the workforce to cater high cost of living and to assist the family's economy financially. Fatima and Sultana (2009) identified the relationship of women participation and economic development in their study. During working hours, it is nearly impossible for parents to look after their children, thus creating the needs to send them under childcare service. In the world lived today, it has become a huge necessity of families to rely on childcare services. Childcare services are used to describe the care of a child during the day by a person other than the child's parents or legal guardians, typically someone outside the child's immediate family. Generally, childcare is used for two different functions namely 1) to free a parent, particularly the mother, to enter the paid work and 2) to foster physical, emotional, cognitive and social development of children. 
In the meantime, the parents are concerned with the good quality services served by childcare centers. This is due to service quality being a dominant feature that leads to customer satisfaction. Many studies have shown that the capability to influence a customer's perception on service performance is based on what they had encountered before. Moreover, the intention to revisit or choose the best service provider in the future as an indicator of service quality satisfaction. The providers need to improve their approaches in order to persist in the current market requirements for a larger market share, loyalty and return of market investment (Coelho \& Henseler, 2012). Besides, the competitive nature in the market had revealed the importance of service providers to pay utmost attention on relationship marketing to persist in the market. This is due to relationship marketing approach being an involvement of trust, risk reduction, value creation, and long term partnership establishment and development (Lin \& Lu, 2010). Egan (2010) pointed out that positive evaluation of service quality will further lead to customer satisfaction based upon the value received, which in turn impact the relationship strength and profitability. Stated otherwise, service quality plays its main role as the catalyst in relationship marketing which will have vast impact to customer satisfaction, which eventually influence behavioral intention among customers. Many service providers are realizing that the needs for success are coming from strategic relationship marketing efforts particularly by evaluation of customers' future intention (Chien, Chia, \& Yuan, 2010).

The study of children development in childcare centers and caregivers have been widely studied for many years (Gupta \& Simonsen, 2010; Hansen \& Hawkes, 2009; Raj \& Raval, 2013). Nonetheless, the service providers are less concerned over the issues of children safety due to the growth of childcare centers in the market. Cases concerning safety and quality of childcare centers in Malaysia have proven that further improvements are required since those cases are related to maltreatment and negligence (Mashitah, Nik Salida, \& Arasy, 2018; Nabiha, Hayati, \& Hejar, 2015). Therefore, the aim of this study is to measure parental perceptions of childcare service quality in Malaysia.

\section{Service Quality}

Based on reviews from related literatures, it is evident that quality plays an important component in marketing issues. As a matter of fact, measuring service quality in different angles and techniques have been discussed by many scholars and they require continuous changes in adapting with environment (Jham, 2018). The concept of service quality has been widely debated and studied since several decades ago due to its effects to customer satisfaction (Kassim \& Asiah Abdullah, 2010; Lily \& Mohamed, 2013; Mubbsher \& Mariam, 2014), it boosts organizational image (Heri, 2017; Ryu, Lee, \& Gon Kim, 2012; Wu \& Li, 2014) and it leads to positive customer behaviors such as re-use intention, recommendation and loyalty (Aliman \& Mohamad, 2013; Liat, Mansori, \& Huei, 2014). Therefore, service quality is useful to service providers to distinguish the customers' perceptions of service quality to overcome competitors and to retain valued customers.

The concepts of service quality have attracted researchers, managers and practitioners due to their extensive effects to satisfaction, profitability, operational cost cutback, loyalty enhancement and business performance's improvement, making service quality being the key objective to gain competitive advantage (Angelova \& Zekiri, 2011). Scholars have asserted that in order for 
improvements and values to be added to service renders to customers, the managements or service providers have to comprehend what actually constitutes the service quality and how it should be measured (Awan, Bukhari, \& Iqbal, 2011). To measure service quality, Parasuraman, Zeithaml, and Berry (1985) identified ten beneficial requirements for customers' evaluation over services quality: 1) reliability, 2) responsiveness, 3) tangibles, 4) communication, 5) credibility, 6) security, 7) competence, 8) courtesy, 9)understanding customers, and 10) service accessibility \& simplified service quality scale SERVQUAL (SERVQUAL being an acronym for service quality), into five dimensions of service quality: 1) reliability, 2) responsiveness, 3) assurance, 4) empathy and 5) tangibles (Parasuraman, Zeithaml, \& Berry, 1988). These scales are the constructs that are found to have high correlations and regarded as to broaden the discrepancy in the middle of the customers' expectations and perceptions (Grönroos, 2004).

There have been several attempts made by a group of researchers who have systematically identified the variables that quantify service quality, among which the two most popular metrics are SERVQUAL and SERVPERF. Cronin and Taylor (1992) had developed service performance (SERVPERF), which was carved out from SERVQUAL. SERVPERF uses to measure service quality by using the customer's perception. This is due to argument by Cronin and Taylor that only perception was sufficient for measuring service quality. Therefore, Cronin and Taylor (1992) recommended the SERVPERF model that was based on performance in the service quality measurement. They claimed that in the service quality measurement SERVPERF is more inclusive that SERVQUAL. Some researchers applied SERVPERF to measure the service quality in the various industries (Chahal \& Kumari, 2010; Qin, Prybutok, \& Zhao, 2010).

With regard to service quality, childcare plays an important role in Malaysian family institution growth. Nowadays, parent have to be prepare with the excellent current education system in Malaysia in producing the future and sustainable generation had made the parent intention to seek the assistance from the center. Government also supports in term of childcare policy and enhancing the facilities and services to ensure parent and children are demands are met. Childcare quality is major aspect of essential service needed by parent and they are relying for accessible, affordable and reliable quality. It provides with variety of services including social and healthcare as well as early education. However if the service render not reaching the require standard this can relate to many cases of injury, negligence and to extend of children death and the provider must focus on this matter in order to tarnish their business reputation (Nabiha et al., 2015). This situation creates a bad remark to childcare. There are some do not provide a proper facilities, unfriendly staffs, improper educational tools that are supposed to grow children ability, particularly in developing the minds of children. This is due to the main goal of customer is to be served from the money they spend for, make a positive significance long-term relationship (Barshan, Elahi, \& Aghaei, 2017).

\section{Methodology}

This empirical study was conducted using data collected from parents who sent their children to any childcare centers. A questionnaire was designed to ask parents on their behavioral intention over childcare's service quality and satisfaction. This information was collected using a five-point scale in response to statements about these variables. A total of 150 self-administered questionnaires were 
distributed to respondents living in Kelantan and Terengganu. One month data collection duration was exercised, with 120 participants being considered as legitimate and having met the requirements (response rate of $80 \%$ ). The questionnaire was divided into two sections. Section $A$ inquired the respondents regarding demographic. Section $B$ inquired about the measurements for service quality. Each item in section B was measured using 5 point Likert Scale ( 1 = Strongly Disagree, 5 = Strongly Agree). The data then was later analyzed using SPSS 20.0 to obtain the result. Table 1 depicts the Cronbach's Alpha scores for the dimensions. The reliability test was conducted to check the internal consistency of the scales. The reliability coefficients of the five dimensions exhibit consistency and service quality as measured by 22 items. The Cronbach's Alpha of tangible consists of 6 items that produced 0.81 , reliability with 4 items yield a coefficient value of 0.68 , followed by responsiveness that carried 4 item with coefficient of 0.86 , assurance and empathy had four items with the value of 0.84 and 0.93 respectively. Therefore, the results for all dimensions studied were considered as reliable. This is consistent with Sekaran and Bougie (2010) who quoted that for all dimensions ranging from 0.62 to 0.95 , they must exceed the minimum acceptable reliability with alpha at 0.6. Additionally, the reliability of alpha value ranging in the above scale has fulfilled the minimum requirement suggested by Nunnally (1978).

Table 1: Reliability Test

\begin{tabular}{ccc}
\hline Dimension & Items & Cronbach's Alpha coefficient \\
\hline Tangible & 6 & 0.81 \\
Reliability & 4 & 0.68 \\
Responsiveness & 4 & 0.86 \\
Assurance & 4 & 0.84 \\
Empathy & 4 & 0.93 \\
\hline
\end{tabular}

\section{Findings and Discussion}

The study analyzed 120 respondents as shown in Table 2 . The demographic data included information of gender, education level, age, race and type of childcare in the areas of Kelantan and Terengganu. The gender of the sample comprised male (44\%) and female (56\%) respondents. In term of education, more than half of them were Bachelor holders (50.8\%). Most respondents' age ranged between $30-$ 39 years old $(46.7 \%)$, followed by $32.5 \%$ by those aged $40-49$ years old, and the least respondents were above 50 years old. For race, the majority of the respondents were Malays (81.7\%), Indians $(12.5 \%)$, Chinese (5\%), and other races $(0.8 \%)$. Respondents were divided into four types of childcare selections: government-based childcare, workplace childcare, institutional or private childcare, and home-based childcare. 61 respondents chose to send their children to private childcare, 32 were attached to home-base, followed by 19 who were involved in government-based childcare, and the remaining of 8 respondents preferred for work-based childcare. 
INTERNATIONAL JOURNAL OF ACADEMIC RESEARCH IN BUSINESS AND SOCIAL SCIENCES

Vol. 9, No. 2, Feb, 2019, E-ISSN: $2222-6990$ ๑ 2019 HRMARS

Table 2: Demographic Profiles

\begin{tabular}{lcc}
\hline Variable & Frequency & Percentage \\
\hline Gender & 53 & 44 \\
Male & 67 & 56 \\
Female & & \\
Education & 24 & 20 \\
SPM & 3 & 2.5 \\
STPM & 16 & 13.3 \\
Cert/ Diploma & 61 & 50.8 \\
Bachelor & 12 & 10.0 \\
Master & 4 & 3.3 \\
PhD & & \\
Age & 22 & 18.3 \\
21-29 & 56 & 46.7 \\
30-39 & 39 & 32.5 \\
40-49 & 3 & 2.5 \\
More than 50 & & \\
Race & 98 & 81.7 \\
Malay & 6 & 5.0 \\
Chinese & 15 & 12.5 \\
Indian & 1 & 0.8 \\
Others & & \\
Types of childcare & 19 & 15.8 \\
Government-owned childcare & 8 & 6.7 \\
Workplace childcare & 61 & 50.8 \\
Private childcare & 32 & 26.7 \\
Home-based childcare &
\end{tabular}

The mean and standard deviation for all measures were 22 items in service quality, 6 items for tangible and 4 items for reliability, responsiveness, assurance and empathy respectively as shown in Table 3. All scales range from one to five. With regard to tangible, most respondents agreed that the care room hygienic $(M=4.24)$ is more important and the least mean $(M=3.12)$ falls for indoor and outdoor facilities. Respondents were concerned with hygienic environment for their children. The finding recorded that the operation hours $(M=4.16)$ gave the highest mean for reliability and menu requirement is less concerned by the respondents $(M=3.85)$ for reliability dimension. The adherence of operation hour is important to help parents to manage their time effectively. The respondents also expect the childcarer to promptly inform if their children were sick and take necessary action for the items in responsiveness $(M=4.40)$. Though ranked last, the item for responding to parents' and children's needs score 4.20 , showing that parents are very concerned for immediate assistance from the centers.

The childcare centers should be reliable and trust-gaining by making the parents confidence and secure having the highest mean score for assurance dimension ( $M=4.26)$. Qualification and 
knowledge among the childcarer portray the mean score of 4.10 . The parents believe that the attitude and skills of a childcarer can develop because of managing the children. The last dimension of empathy reflects that the respondents expect the childcarer to pay attention and give love to children ( $M=4.21$ ). The mean score of 4.07 interprets that the childcarer should know the individual character and potential of the children. Thus, the overall mean for each dimension are responsive $(M=4.27)$, assurance $(M=4.23)$, empathy $(M=4.15)$, reliability $(M=4.01)$, and tangible $(M=3.89)$. Looking in this study, the childcare center's responsiveness is becoming an important factor amongst the parent. The childcare center should train their child carers in delivering the service and need to be empowered to address service outcomes.

Table 3: Descriptive Statistics

\begin{tabular}{lcc}
\hline Dimensions & Mean & Standard Deviation \\
\hline Tangible & & \\
Care room hygienic & 4.24 & 0.68 \\
Room well equip & 4.20 & 0.92 \\
Safety equipment & 4.07 & 0.83 \\
Tools aids & 3.90 & 1.08 \\
Kitchen hygienic & 3.81 & 0.70 \\
Indoor outdoor facilities & 3.12 & 1.02 \\
Reliability & & \\
Operation hours & 4.16 & 0.83 \\
Fast respond & 4.06 & 0.77 \\
Record confidential & 3.95 & 0.85 \\
Menu requirement & 3.85 & 0.94 \\
Responsiveness & & \\
Children sick & 4.40 & 0.67 \\
Responsibility and love & 4.27 & 0.67 \\
Frequent interaction & 4.22 & 0.70 \\
Parent needs & 4.20 & 0.71 \\
Assurance & & \\
Reliable and trusted & 4.26 & 0.85 \\
Good experiences & 4.25 & 0.75 \\
Portrays positive attitude & 4.23 & 0.71 \\
Qualification and knowledge & 4.17 & 0.72 \\
Empathy & & \\
Attention and love & 4.21 & 0.74 \\
Satisfied and interact with & 4.17 & 0.68 \\
Observant & 4.13 & 0.76 \\
Disposition and character & 4.07 & 0.82 \\
\hline
\end{tabular}


INTERNATIONAL JOURNAL OF ACADEMIC RESEARCH IN BUSINESS AND SOCIAL SCIENCES

Vol. 9, No. 2, Feb, 2019, E-ISSN: 2222-6990 C 2019 HRMARS

\section{Conclusion}

Service quality is the best tools in marketing service providers to find and analyze information about the customer needs, wants, and perceptions about services. This information will help them to identify problems and make strategic plans in order to improve efficiency, profitability, and overall performance by high service quality.

To reiterate, this study was done to determine the childcare service quality perceived by Kelantan and Terengganu's parents based on SERVPERF dimensions. The respondents that were referred to working parents identified the criteria expected in childcare centers when leaving their children to childcarer. Based on the results, the study concludes that the childcare centers must render the high expectation of service to accommodate the demands of parents. Therefore, the findings of the study show that all the five dimensions of service quality are mandatory to be exercised by the childcare service providers to avoid disappointing the customer's expectation.

\section{Note}

The author is a lecturer of Marketing at University Malaysia Kelantan, Malaysia. This article was prepared while she was on study leave for her PhD study at University Malaysia Terengganu under the supervision of Assoc. Professor Dr Safiek Mokhlis and senior lecturer, Dr Hayatul Safrah Salleh.

\section{References}

Abas, A., \& Noor, M. H. M. (2018). Wan Azizah : 38,333 creches needed for kids under 4. https://www.nst.com.my

Aliman, N. K., \& Mohamad, W. N. (2013). Perceptions of service quality and behavioral intentions: A mediation effect of patient satisfaction in the private health care in Malaysia. International Journal of Marketing Studies, 5(4). doi:http://dx.doi.org/10.5539/ijms.v5n4p15

Angelova, B., \& Zekiri, J. (2011). Measuring Customer Satisfaction with Service Quality Using American Customer Satisfaction Model (ACSI Model). International Journal of Academic Research in Business and Social Sciences, 1(3), 27.

Awan, H. M., Bukhari, K. S., \& Iqbal, A. (2011). Service quality and customer satisfaction in the banking sector- a comparative study of conventional and Islamic banks in Pakistan. Journal of Islamic Marketing, 2(3), 203-224.

Barshan, G., Elahi, A., \& Aghaei, N. (2017). Impact of service quality on satisfaction, loyalty and intention to revisit of sport customers- The case study of swimming pools in Alborz Province. International Review of Management and Marketing, 7(2), 334-339.

Chahal, H., \& Kumari, N. (2010). Development of multidimensional scale for healthcare service quality (HCSQ) in Indian context. Journal of Indian Business Research, 2(4), 230-255. doi:10.1108/09526860910964834

Chien, H. L., Chia, L. C., \& Yuan, D. D. (2010). Effect of commitment and trust towards micro-blogs on consumer behavioral intention. A relationship marketing perspective pdf. International Journal of Electronic Business Management, 8(4), 292-303.

Coelho, P. S., \& Henseler, J. (2012). Creating customer loyalty through service customization. European Journal of Marketing, 46(3/4), 331-356. 
INTERNATIONAL JOURNAL OF ACADEMIC RESEARCH IN BUSINESS AND SOCIAL SCIENCES

Vol. 9, No. 2, Feb, 2019, E-ISSN: 2222-6990 C 2019 HRMARS

Cronin, J. J., \& Taylor, S. (1992). Measuring service quality- A reexamination and extension., 56(3), 5568.

Egan, J. (2010). Relationship Marketing Exploring relational strategies in marketing. In.

Fatima, A., \& Sultana, H. (2009). Tracing out the U-shape relationship between female labor force participation rate and economic development for Pakistan. International Journal of SocialEconomics, 36(1/2), 182-198.

Grönroos, C. (2004). The relationship marketing process: communication, interaction, dialogue, value. Journal of Business \& Industrial Marketing, 19(2), 99-113.

Gupta, N. D., \& Simonsen, M. (2010). Non-cognitive child outcomes and universal high quality child care. Journal of Public Economics, 94(1-2), 30-43.

Hansen, K., \& Hawkes, D. (2009). Early childcare and child development. Journal of Social Policy, 38(02).

Heri, H. (2017). Analysis the effect of service quality, customers value, customer satisfaction and customer trust on corporate image. Journal of Business and Management, 19(6), 38-46.

Jham, V. (2018). Customer satisfaction, service quality, consumer demographics, and word of mouth communications perspectives: Evidence from the retail banking in United Arab Emirates. Academy of Marketing Studies, 22(3), 1-17.

Kassim, N., \& Asiah Abdullah, N. (2010). The effect of perceived service quality dimensions on customer satisfaction, trust, and loyalty in e-commerce settings. Asia Pacific Journal of Marketing and Logistics, 22(3), 351-371.

Liat, C. B., Mansori, S., \& Huei, C. T. (2014). The Associations between service quality, corporate image, customer satisfaction, and loyalty: Evidence from the Malaysian Hotel Industry. Journal of Hospitality Marketing \& Management, 23(3), 314-326.

Lily, M. M., \& Mohamed, N. A. A. (2013). Preschool education in Malaysia- Emerging trends and implications for the future. American Journal of Economics, 3(6), 347-351.

Lin, L. Y., \& Lu, C. Y. (2010). The influence of corporate image, relationship marketing, and trust on purchase intention: the moderating effects of word-of-mouth. Tourism Review, 65(3), 16-34.

Mashitah, A. M., Nik Salida, S. N. S., \& Arasy, M. (2018). Quality enhancement of childcare centres in Malaysia- An analysis on laws and regulations. Journal of Education and Social Sciences,, 9(1), 23-28.

Mubbsher, M. K., \& Mariam, F. (2014). Impact of service quality on customer satisfaction and customer loyalty- Evidence from Banking Sector. Pakistan Journal of Commerce and Social Sciences, 8(2), 331-354.

Nabiha, G., Hayati, K., \& Hejar, A. (2015). A Protocol on Factors Influencing Safety Practices for Injury Prevention amongst Children in day-Care Centres in Selangor and Putrajaya . International Journal of Public Health and Clinical Sciences, 1(2), 191-203.

Nunnally, J. C. (1978). Psychometric Theory (2nd ed.). In.

Parasuraman, A., Zeithaml, V. A., \& Berry, L. L. (1985). A conceptual model of Service Quality and its implication for future research. Journal of Marketing, 49, 41-50.

Parasuraman, A., Zeithaml, V. A., \& Berry, L. L. (1988). SERVQUAL A Multiple Item Scale for measuring Customer Perceptions of Service Quality. Journal of Retailing, 64(1), 12-40. 
Qin, H., Prybutok, V. R., \& Zhao, Q. (2010). Perceived service quality in fast-food restaurantsempirical evidence from China. International Journal of Quality \& Reliability Management, 27(4), 424-437. doi:10.1108/02656711011035129

Raj, S. P., \& Raval, V. V. (2013). Residential child care in Malaysia: An exploratory qualitative study of caregiver-child interactions. International Perspectives in Psychology: Research, Practice, Consultation, 2(3), 194-206. doi:10.1037/a0032751

Ryu, K., Lee, H. R., \& Gon Kim, W. (2012). The influence of the quality of the physical environment, food, and service on restaurant image, customer perceived value, customer satisfaction, and behavioral intentions. International Journal of Contemporary Hospitality Management, 24(2), 200-223.

Sekaran, U., \& Bougie, R. (2010). Research Method for Business: A Skill Building Approach (5th ed.). New Jersey: John Wiley \& Sons.

Wu, H.-C., \& Li, T. (2014). A Study of Experiential Quality, Perceived Value, Heritage Image, Experiential Satisfaction, and Behavioral Intentions for Heritage Tourists. Journal of Hospitality \& Tourism Research, 41(8), 904-944. 